\title{
Effect of garlic on blood pressure: A systematic review and meta-analysis
}

\author{
Karin Ried*1, Oliver R Frank ${ }^{1}$, Nigel P Stocks ${ }^{1}$, Peter Fakler ${ }^{1}$ and \\ Thomas Sullivan ${ }^{2}$
}

\author{
Address: ${ }^{1}$ Discipline of General Practice, The University of Adelaide, Adelaide, South Australia and ${ }^{2}$ Discipline of Public Health, The University of \\ Adelaide, Adelaide, South Australia \\ Email: Karin Ried* - karin.ried@adelaide.edu.au; Oliver R Frank - oliver.frank@adelaide.edu.au; Nigel P Stocks - nigel.stocks@adelaide.edu.au; \\ Peter Fakler - pfakler@bigpond.net.au; Thomas Sullivan - thomas.sullivan@adelaide.edu.au \\ * Corresponding author
}

Published: 16 June 2008

BMC Cardiovascular Disorders 2008, 8:13 doi:10.1186/147|-2261-8-13

This article is available from: http://www.biomedcentral.com/I47I-226I/8//3

(C) 2008 Ried et al; licensee BioMed Central Ltd.

This is an Open Access article distributed under the terms of the Creative Commons Attribution License (http://creativecommons.org/licenses/by/2.0), which permits unrestricted use, distribution, and reproduction in any medium, provided the original work is properly cited.
Received: 26 March 2008

Accepted: 16 June 2008

\begin{abstract}
Background: Non-pharmacological treatment options for hypertension have the potential to reduce the risk of cardiovascular disease at a population level. Animal studies have suggested that garlic reduces blood pressure, but primary studies in humans and non-systematic reviews have reported mixed results. With interest in complementary medicine for hypertension increasing, it is timely to update a systematic review and meta-analysis from 1994 of studies investigating the effect of garlic preparations on blood pressure.
\end{abstract}

Methods: We searched the Medline and Embase databases for studies published between 1955 and October 2007. Randomised controlled trials with true placebo groups, using garlic-only preparations, and reporting mean systolic and/or diastolic blood pressure (SBP/DBP) and standard deviations were included in the meta-analysis. We also conducted subgroup meta-analysis by baseline blood pressure (hypertensive/normotensive), for the first time. Meta-regression analysis was performed to test the associations between blood pressure outcomes and duration of treatment, dosage, and blood pressure at start of treatment.

Results: Eleven of 25 studies included in the systematic review were suitable for meta-analysis. Meta-analysis of all studies showed a mean decrease of $4.6 \pm 2.8 \mathrm{~mm} \mathrm{Hg}$ for SBP in the garlic group compared to placebo $(n=10 ; p=0.001)$, while the mean decrease in the hypertensive subgroup was $8.4 \pm 2.8 \mathrm{~mm} \mathrm{Hg}$ for SBP $(n=4 ; p<0.00 \mathrm{I})$, and $7.3 \pm 1.5 \mathrm{~mm} \mathrm{Hg}$ for DBP $(n=3 ; p<0.00 \mathrm{I})$. Regression analysis revealed a significant association between blood pressure at the start of the intervention and the level of blood pressure reduction (SBP: $R=0.057 ; p=0.03$; $D B P: R=-0.315$; $\mathrm{p}=0.02)$.

Conclusion: Our meta-analysis suggests that garlic preparations are superior to placebo in reducing blood pressure in individuals with hypertension. 


\section{Background}

Hypertension (systolic blood pressure (SBP) $\geq 140 \mathrm{~mm}$ $\mathrm{Hg}$; diastolic blood pressure (DBP) $\geq 90 \mathrm{~mm} \mathrm{Hg}$ ) is a known risk factor for cardiovascular morbidity and mortality, affecting an estimated 1 billion individuals worldwide [1]. Recently updated guidelines for the treatment of high blood pressure stress the importance of preventive strategies, and recommend extending the management of blood pressure to include pre-hypertensive individuals (SBP 120-139/DBP 80-89 mm Hg) [1]. Primary management should include relevant lifestyle modifications such as increased exercise, weight loss and dietary changes which could incorporate dietary supplementation.

Garlic (Allium sativum) has played an important dietary as well as medicinal role in human history [2]. Blood pressure reducing properties of garlic have been linked to its hydrogen sulphide production [3] and allicin content liberated from alliin and the enzyme alliinase $[4,5]-$ which has angiotensin II inhibiting and vasodilating effects, as shown in animal and human cell studies $[3,6-$ $10]$.

Primary studies in humans and reviews of garlic preparations and blood pressure have been inconclusive [11-40]. A meta-analysis published in 1994 reported promising results in subjects with mild hypertension but found insufficient evidence to recommend garlic for clinical therapy [41]. The increasing use of alternative and complementary therapies for hypertension $[42,43]$ makes it timely to provide an updated systematic review and metaanalysis of trials investigating the effect of garlic preparations on blood pressure. Inclusion of additional data from studies published since 1994 has enabled subgroup metaanalyses of hypertensive and normotensive subjects.

\section{Methods}

\section{Literature search}

We searched the Medline, Embase and Cochrane databases for studies published between 1955 and Oct 2007 using the search terms [garlic AND ("blood pressure" OR hypertens* OR pre-hypertens* OR prehypertens*)] to identify intervention studies investigating the effect of garlic on blood pressure. We also checked reference lists of previously published systematic reviews and meta-analyses for additional primary studies $[36,41]$.

\section{Study selection}

In the systematic review we included published intervention studies (these included randomised controlled trials and non-placebo controlled trials), reporting effects of garlic on blood pressure and published in English or German (Table 1 and Additional File 1). Stricter criteria were required for inclusion in meta-analysis: Only studies with placebo control groups, using garlic-only supplements, and reporting mean systolic and/or diastolic blood pressure (SBP/DBP) and standard deviation (SD) were eligible for meta-analysis (Table 1). We contacted authors of studies with suitable study design but incomplete published data (mean SBP/DBP or SD) to retrieve complete data sets for meta-analysis. Figure 1 summarises the study selection process.

\section{Data extraction and quality assessment for meta-analysis}

The number of subjects in intervention and control groups, mean SBP and DBP at start and end of intervention and SD were collated from text, tables or figures. Methodological quality was assessed independently by two investigators (KR and $\mathrm{PF}$ ) using guidelines by the Cochrane Collaboration [44] (Tables 2 and 3), and disagreements were resolved by consensus. All studies considered for meta-analysis $(\mathrm{n}=11$, Table 2$)$ reported adequate randomisation and double blinding, and all but one [14] assessed blood pressure as co-primary outcome measure. Six of eleven studies reported drop-out rates between 0 and $13 \%[13,14,17,18,20,21]$, two studies of less than $22 \%[15,19]$, and three studies did not provide details $[11,12,16]$. We considered the quality of all eleven studies as sufficient to be included in meta-analysis.

\section{Data synthesis and meta-analysis}

Changes in mean SBP or DBP of garlic and control groups before and after intervention were entered into the metaanalysis using Review Manager version 4.2 [45]. Standard deviations of these differences were estimated applying the equation published in Taubert et al. [46] and using a conservative correlation coefficient of $\mathrm{R}=0.68$ as suggested by the Cochrane Handbook for Systematic Reviews of Interventions [44]. If heterogeneity was high $\left(\mathrm{I}^{2}>50 \%\right)$ we used the random effects model for meta-analysis, otherwise the fixed effects model was considered appropriate $[47,48]$.

In addition, we performed subgroup meta-analysis of trials with hypertensive subjects at start of treatment (mean $\mathrm{SBP} \geq 140 \mathrm{~mm} \mathrm{Hg}$ or mean $\mathrm{DBP} \geq 90 \mathrm{~mm} \mathrm{Hg}$ ) and subgroup analysis of trials with normotensive subjects at start of treatment (mean SBp $<140$ mm Hg or mean DBp $<90$ $\mathrm{mm} \mathrm{Hg}$ ).

Potential publication bias in the meta-analysis was assessed by Begg's funnel plots and Egger's regression test $[49,50]$.

Meta-regression was performed to find any association between blood pressure changes over time and the following continuous variables: dosage, length of intervention, and blood pressure at start of treatment. We also tested for any evidence of confounding related to source of funding 
Table I: Characteristics of randomised controlled trials included in meta-analysis examining the effect of garlic on blood pressure

\begin{tabular}{|c|c|c|c|c|c|}
\hline Source & $\begin{array}{l}\text { Study design; } \\
\text { Intervention/ } \\
\text { control groups }\end{array}$ & $\begin{array}{l}\text { Type of garlic } \\
\text { preparation, } \\
\text { Dosage, Duration }\end{array}$ & $\begin{array}{l}\text { Number of } \\
\text { participants in } \\
\text { intervention vs } \\
\text { control group }\end{array}$ & $\begin{array}{l}\text { Mean SBP (SD) at } \\
\text { start/end of } \\
\text { intervention vs } \\
\text { control in } \mathrm{mm} \mathrm{Hg}\end{array}$ & $\begin{array}{l}\text { Mean DBP (SD) at } \\
\text { start/end of } \\
\text { intervention vs } \\
\text { control in } \mathrm{mm} \mathrm{Hg}\end{array}$ \\
\hline \multirow[t]{3}{*}{$\begin{array}{l}\text { Kandziora J } 1988 \\
\text { (Study I), [II] }\end{array}$} & Parallel, & Garlic powder (Kwai), & $20 / 20$ & $\begin{array}{l}\text { Garlic: } 174(4) / 158 \\
(10)\end{array}$ & Garlic: 99 (3)/83 (4) \\
\hline & $\begin{array}{l}\text { Diuretic drug (Dytide } \\
\mathrm{H})+ \text { garlic/drug only }\end{array}$ & $600 \mathrm{mg} / \mathrm{d}$ & (standing) & $\begin{array}{l}\text { Control: } 175(8) / 169 \\
\text { (6) }\end{array}$ & Control: $98(5) / 90(3)$ \\
\hline & & 12 wks & & & \\
\hline \multirow[t]{3}{*}{ Auer et al. 1990, [12] } & Parallel, & Kwai, & $24 / 23$ & $\begin{array}{l}\text { Garlic: } 17 \mid(21.6) / 152 \\
(19.6)\end{array}$ & $\begin{array}{l}\text { Garlic: } 102 \text { (13)/89 } \\
(4.4)\end{array}$ \\
\hline & Garlic/placebo & 600 mg/d, & & $\begin{array}{l}\text { Control: } 161 \text { (19)/153 } \\
\text { (19) }\end{array}$ & $\begin{array}{l}\text { Control: } 97 \text { (12.9)/93 } \\
(10.6)\end{array}$ \\
\hline & & 12 wks & & & \\
\hline \multirow[t]{3}{*}{$\begin{array}{l}\text { Vorberg \& Schneider } \\
\text { 1990, [13] }\end{array}$} & Parallel, & Kwai, & $20 / 20$ & $\begin{array}{l}\text { Garlic: I } 44.5 \text { (13.4)/ } \\
\text { I } 38.5(4.3)\end{array}$ & $\begin{array}{l}\text { Garlic: 9I (3.9)/87 } \\
(3.7)\end{array}$ \\
\hline & Garlic/placebo & 900 mg/d, & & $\begin{array}{l}\text { Control: I44 (10.4)/ } \\
\text { I47 (7.I) }\end{array}$ & $\begin{array}{l}\text { Control: } 88 \text { (6.I)/90 } \\
\text { (3.7) }\end{array}$ \\
\hline & & 16 wks & & & \\
\hline \multirow[t]{3}{*}{$\begin{array}{l}\text { Holzgartner et al. } \\
\text { 1992, [14] }\end{array}$} & Parallel, & Kwai, & $47 / 47$ & $\begin{array}{l}\text { Garlic: I } 43.4(15.4) / \\
\text { I35.4 (I4.6) }\end{array}$ & $\begin{array}{l}\text { Garlic: } 82.8(10.5) / \\
78.6(9.3)\end{array}$ \\
\hline & $\begin{array}{l}\text { Lipid-lowering drug } \\
\text { (Benzafibrate) }+ \\
\text { garlic/drug only }\end{array}$ & 900 mg/d, & & $\begin{array}{l}\text { Control: I40.6 (I8.7)/ } \\
\text { I37.2 (14.6) }\end{array}$ & $\begin{array}{l}\text { Control: } 82.4 \text { (9.5)/ } \\
78.4 \text { (9.2) }\end{array}$ \\
\hline & & 12 wks & & & \\
\hline \multirow[t]{3}{*}{$\begin{array}{l}\text { Kiesewetter et al. } \\
\text { 1993, [15] }\end{array}$} & Parallel, & Kwai, & $32 / 32$ & Not reported & $\begin{array}{l}\text { Garlic: } 84.7(13.7) / \\
81.7 \text { (I2.1) }\end{array}$ \\
\hline & Garlic/placebo & 800 mg/d, & & & $\begin{array}{l}\text { Control: } 83.3(\mathrm{II}) / \\
81.7(\mathrm{II})\end{array}$ \\
\hline & & 12 wks, & & & \\
\hline \multirow[t]{3}{*}{ Jain et al. 1993, [16] } & Parallel, & Kwai, & $20 / 22$ & $\begin{array}{l}\text { Garlic: } 129(13) / 130 \\
\text { (17) }\end{array}$ & Garlic: $82(6) / 8 \mid$ (10) \\
\hline & Garlic/placebo & 900 mg/d, & & $\begin{array}{l}\text { Control: } 128(10) / 127 \\
(12)\end{array}$ & Control: $83(8) / 82(6)$ \\
\hline & & 12 wks & & & \\
\hline \multirow[t]{3}{*}{$\begin{array}{l}\text { Saradeth et al. 1994, } \\
\text { [17] }\end{array}$} & Parallel, & Kwai, & $25 / 27$ & $\begin{array}{l}\text { Garlic: } 125(17) / 127.4 \\
\text { (16) }\end{array}$ & $\begin{array}{l}\text { Garlic: } 80.8(8) / 82.7 \\
(10)\end{array}$ \\
\hline & Garlic/placebo & 600 mg/d, & & $\begin{array}{l}\text { Control: } 124.6(15.6) / \\
\text { I22.8 (I2.5) }\end{array}$ & $\begin{array}{l}\text { Control: } 81.8(9.4) / \\
81.1(9.4)\end{array}$ \\
\hline & & 15 wks & & & \\
\hline \multirow[t]{3}{*}{$\begin{array}{l}\text { Simons et al. 1995, } \\
\text { [18] }\end{array}$} & Crossover, & Kwai, & $28 / 28$ & $\begin{array}{l}\text { Garlic: } 127(14) / 119 \\
\text { (7) }\end{array}$ & Garlic: 80 (8)/76 (5) \\
\hline & Garlic/placebo & 900 mg/d, & & $\begin{array}{l}\text { Control: } 127(14) / 122 \\
(10)\end{array}$ & Control: $80(8) / 76(6)$ \\
\hline & & 12 wks & & & \\
\hline \multirow[t]{3}{*}{$\begin{array}{l}\text { Steiner et al. 1996, } \\
\text { [19] }\end{array}$} & Parallel study arm, & Aged garlic extract, & $4 I / 4 I$ & $\begin{array}{l}\text { Garlic: } 134(14) / 126 \\
\text { (14) }\end{array}$ & $\begin{array}{l}\text { Garlic: } 84(8.6) / 82.3 \\
\text { (9) }\end{array}$ \\
\hline & Garlic/placebo & 2400 mg/d, & & $\begin{array}{l}\text { Control: I34 (II)/ } \\
\text { I29.6(I2) }\end{array}$ & $\begin{array}{l}\text { Control: } 85(7.4) / 81.7 \\
\text { (8) }\end{array}$ \\
\hline & & 23 wks & & & \\
\hline \multirow[t]{3}{*}{$\begin{array}{l}\text { Adler \& Holub 1997, } \\
\text { [20] }\end{array}$} & Parallel, & Kwai, & $12 / 13 / 10 / 1 \mid$ & $\begin{array}{l}\text { Garlic: I } 23.3(14.5) / \\
\text { I I8.5 (9.4) }\end{array}$ & $\begin{array}{l}\text { Garlic: } 83.2(2.5) / 80 \\
(2.2)\end{array}$ \\
\hline & $\begin{array}{l}\text { Garlic/garlic+fish oil/ } \\
\text { fish oil/placebo }\end{array}$ & 900 mg/d, & & $\begin{array}{l}\text { Control: II } 8.3(3.2) / \\
\text { II } 9.6(3)\end{array}$ & $\begin{array}{l}\text { Control: } 79.6(2.2) / \\
80.9(2)\end{array}$ \\
\hline & & 12 wks & & & \\
\hline \multirow[t]{3}{*}{ Zhang et al. 2000, [2I] } & Parallel, & Distilled garlic oil, & $14 / 13$ & $\begin{array}{l}\text { Garlic: II } 17 \text { (8)/II } 3.5 \\
(6.4)\end{array}$ & $\begin{array}{l}\text { Garlic: } 72(7) / 68.2 \\
(9.4)\end{array}$ \\
\hline & Garlic/placebo & 12.3 mg/d, & & $\begin{array}{l}\text { Control: } 109(9) / \\
109.9(9.4)\end{array}$ & $\begin{array}{l}\text { Control: } 64 \text { (7)/62.8 } \\
(5.4)\end{array}$ \\
\hline & & 16 wks & & & \\
\hline
\end{tabular}

SBP, systolic blood pressure; DBP, diastolic blood pressure; SD, standard deviation; vs, versus; $\mathrm{mm} \mathrm{Hg}$, millimetre mercury; mg/d, milligram per day; wks, weeks; mths, months. 


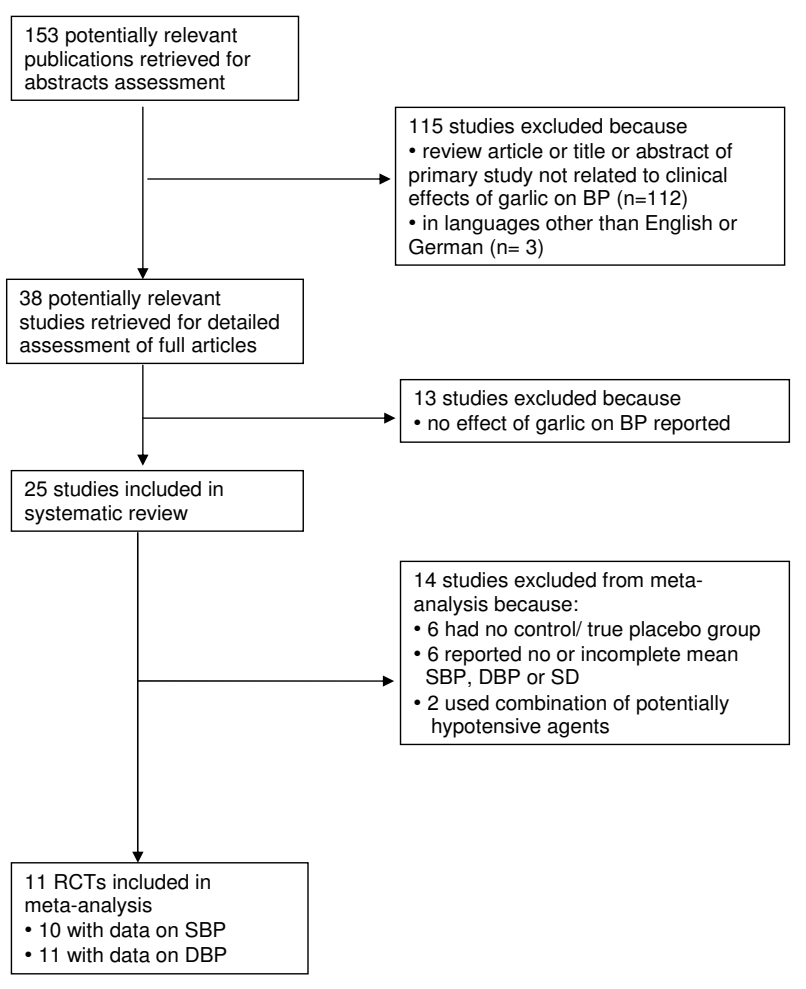

Figure I

Flow diagram of study selection for systematic review and meta-analysis. Abbreviations: $B P$, blood pressure; SBP, systolic blood pressure; DBP, diastolic blood pressure; SD, standard deviation; $R C T$, randomised controlled trial

(details on funding in Tables 2 and 3). Regression analyses were conducted using Stata version 9 [51].

\section{Plotting of blood pressure changes over time}

We integrated additional blood pressure data from studies included in the systematic review in $\mathrm{BP} /$ time plots for visual assessment of BP trends depending on BP at start of treatment (mean/median SBP at start $\geq$ or $<130 \mathrm{~mm} \mathrm{Hg}$, mean/median DBP $\geq$ or $<85 \mathrm{~mm} \mathrm{Hg}$ ). We included in the plots data of placebo and non-placebo controlled trials using garlic-only preparations, and reporting mean or median SBP and/or DBP.

\section{Results}

Eleven of 25 studies included in our systematic review and investigating the effect of garlic on blood pressure met the inclusion criteria for meta-analysis (Table 1) [11-21]. Fourteen studies were excluded from meta-analysis: six had no placebo control group [24,25,28,32,34,35], another six reported incomplete data for mean SBP, DBP or SD $[23,26,27,30,31,33]$, and another two because they used garlic combination supplements containing other potentially hypotensive agents [22,29] (Additional File 1 ). We were able to contact the authors of four studies with suitable study design but incompletely reported data required for meta-analysis $[20,26,27,33]$, and obtained complete data from one study [20].

Ten of the eleven studies included in the meta-analysis reported complete SBP and SD data required for metaanalysis, and eleven studies reported DBP and SD data (Table 1) (DBP data only [15]). Nine studies compared garlic preparations to placebo, and two studies compared the effect of garlic on blood pressure in addition to a drug compared to drug plus placebo [11: diuretic, antihypertensive, acts on sodium chloride reabsorption, 14: lipidlowering drug]. Nine studies used garlic powder (mainly "Kwai", a standardised garlic supplement [52]), one study used aged garlic extract [19] and another used distilled garlic oil [21]. Dosage of garlic powder ranged between 600 and $900 \mathrm{mg}$ per day, and duration of intervention ranged from 12 to 23 weeks. A total of 252 individuals allocated to a garlic intervention group and 251 individuals allocated to a control group were included in the metaanalysis on SBP, and 283 (garlic) versus 282 (control) on DBP. Mean blood pressure at start of intervention varied markedly, with four studies reporting mean SBP in the hypertensive range $(\geq 140 \mathrm{~mm} \mathrm{Hg})$ and three studies reporting mean DBP in the hypertensive range $\geq 90 \mathrm{~mm}$ $\mathrm{Hg}$ ) before treatment.

Meta-analysis of ten studies of the effect of garlic on SBP showed a significant difference between garlic and control groups, with garlic having a greater effect in reducing SBP than placebo by 4.56 [95\% CI (confidence interval), 7.36, -1.77] mm Hg compared with placebo ( $\mathrm{p}<0.001)$ (Figure 2a). Subgroup analysis of studies with mean SBP in the hypertensive range at start of intervention revealed a greater SBP reduction in the garlic group than placebo by 8.38 [95\% CI, -11.13, -5.62] mm Hg ( $\mathrm{p}<0.001)$ (Figure 3a). Subgroup analysis of the remaining studies with mean SBP in the normotensive range $(<140 \mathrm{~mm} \mathrm{Hg})$ at start of intervention showed no significant difference between the garlic and placebo groups (Figure $3 \mathrm{~b}$ ).

Meta-analysis of eleven studies of the effect of garlic on DBP did not show a significant difference between garlic and placebo groups $(-2.44$ [95\% CI, $-4.97,0.09] \mathrm{mm} \mathrm{Hg}$, $\mathrm{p}=0.06$ ) (Figure 2b). However, subgroup analysis of studies with mean DBP in the hypertensive range at the start of treatment revealed a significant difference between garlic and control groups. The results indicate that garlic was more effective in reducing DBP than placebo in hypertensive individuals by 7.27 [95\% CI, -8.77, -5.76] $\mathrm{mm} \mathrm{Hg}(\mathrm{p}<0.001)$ (Figure 3c). In contrast, subgroup meta-analysis of "normotensive" individuals was not significant (Figure 3d). 
Table 2: Assessment of study quality for studies included in meta-analysis

\begin{tabular}{|c|c|c|c|c|c|}
\hline Study ID & Randomisation & Blinding & $\begin{array}{l}\text { Outcome measure: } \\
\text { Blood pressure }\end{array}$ & Loss of follow up & Funding source \\
\hline $\begin{array}{l}\text { Kandziora J } 1988 \text { (Study I), } \\
\text { [II] }\end{array}$ & + & ++ & $\begin{array}{l}\text { Primary, Mean of } 2 \\
\text { readings each standing + } \\
\text { supine }\end{array}$ & Unclear & - \\
\hline Auer et al. 1990, [12] & + & ++ & $\begin{array}{l}\text { Primary, Mean standing + } \\
\text { supine }\end{array}$ & Unclear & - \\
\hline $\begin{array}{l}\text { Vorberg \& Schneider 1990, } \\
\text { [13] }\end{array}$ & + & ++ & $\begin{array}{l}\text { Primary, Mean standing + } \\
\text { supine }\end{array}$ & G: $0 \%, C: 0 \%$ & - \\
\hline $\begin{array}{l}\text { Holzgartner et al. 1992, } \\
\text { [14] }\end{array}$ & + & ++ & Secondary, Unclear & G: $4.8 \% ; C: 4.8 \% ;$ T: $4.8 \%$ & - \\
\hline $\begin{array}{l}\text { Kiesewetter et al. } 1993, \\
{[15]}\end{array}$ & + & ++ & $\begin{array}{l}\text { Primary, Riva Rocci } \\
\text { method }\end{array}$ & G: $20 \%$; C: $20 \%$; T: $20 \%$ & - \\
\hline Jain et al. 1993, [16] & + & ++ & $\begin{array}{l}\text { Primary, Mean of } 2 \\
\text { readings after } 10 \text { min rest; } \\
\text { standard technique (JNC } \\
\text { 1988) }\end{array}$ & Unclear & Industry grant \\
\hline Saradeth et al. 1994, [17] & + & ++ & $\begin{array}{l}\text { Primary, Riva Rocci } \\
\text { method }\end{array}$ & G: $2.8 \% ; C: 8.3 \% ;$ T: $5.6 \%$ & - \\
\hline Simons et al. 1995, [18] & + & ++ & $\begin{array}{l}\text { Primary, Mean of } 2 \\
\text { readings after } 5 \text { min rest, } \\
\text { phase V diastolic BP }\end{array}$ & T: $9.7 \%$ & Industry grant \\
\hline $\begin{array}{l}\text { Steiner et al. 1996, [19] } \\
\text { parallel arm }\end{array}$ & + & ++ & Primary, Unclear, manual & $\mathrm{T}: 21.2 \%$ & - \\
\hline Adler \& Holub 1997, [20] & + & ++ & Primary, Sitting digital & $\mathrm{T}: 8 \%$ & Heart \& Stroke Foundation \\
\hline Zhang et al. $2000,[2 \mathrm{I}]$ & + & ++ & $\begin{array}{l}\text { Primary, Over } 10-30 \mathrm{~min} \\
\text { until repeated low values } \\
\text { were obtained, means of } 3 \\
\text { lowest pulse rates + } \\
\text { associated BP values }\end{array}$ & G: $6.7 \% ; C: 13.3 \% ;$ T: $10 \%$ & Industry grant \\
\hline
\end{tabular}

+: adequate; ++: double blinding; -: not provided

Heterogeneity was moderate for meta-analysis of SBP of all ten studies $\left(I^{2}=57.1 \%\right)$. However, we found no heterogeneity in the subgroup analysis of studies with hypertensive individuals at start of intervention $\left(\mathrm{I}^{2}=0 \%\right)$. The same trend was observed for meta-analysis of DBP with $\mathrm{I}^{2}$ $=83.2 \%$ for pooled analysis of all ten studies and $\mathrm{I}^{2}=0 \%$ for subgroup analysis of studies with hypertensive subjects at start of intervention.

Regression analysis was conducted to test whether heterogeneity between the studies could be explained by one or more of the following continuous variables: dosage (only studies using garlic powder were included, $n=8 / 9$ (SBP/ DBP), range $600-900 \mathrm{mg} / \mathrm{d}$ ), duration of intervention (SBP/DBP: $\mathrm{n}=10 / 11$, range 12-23 wks), and SBP or DBP at start of intervention (SBP/DBP: $n=10 / 11$, range 175109 SBP/102-64 DBP). SBP or DBP at start of intervention proved to be a significant predictor for heterogeneity (SBP: $\mathrm{R}=-0.151, \mathrm{p}=0.03$; DBP: $\mathrm{R}=-0.316, \mathrm{p}=0.02$ ), strengthening the results of subgroup meta-analysis. None of the other variables tested showed a significant association with blood pressure outcomes (data not shown). Furthermore, regression analysis did not provide any evidence to suggest that receipt of industry funding (n $=3$ ) was associated with blood pressure outcomes.
Funnel plots and Egger regression tests suggested no publication bias in the meta-analyses (Figure 4).

Figure 5 augments our systematic review, allowing a visual comparison of BP changes in garlic-only intervention arms of published randomised trials (Table 1 and Additional File 1). Blood pressure changes over time were plotted by blood pressure at start of treatment using data from 20 out of the 25 studies identified in our systematic review, which included placebo and non-placebo controlled trials, using garlic-only preparations, and reporting mean or median SBP and/or DBP (studies in meta-analysis [11-21]; as well as garlic-only intervention arms included in systematic review [24-28,32,33,35,53]). In total, mean or median SBP data was available for 23 garlic-only intervention arms and mean or median DBP data for 24 garlic intervention arms. Studies of groups with high blood pressure (mean SBP or DBP) at start of intervention generally showed a downward trend of blood pressure over time (Figure 5a and 5c). These included studies of groups with high normal blood pressure, also known as pre-hypertension ( $\mathrm{SBP} \geq 130 \mathrm{~mm} \mathrm{Hg}, \mathrm{DBP} \geq 85$ $\mathrm{mm} \mathrm{Hg}$ ). Blood pressure generally changed little for studies of groups with mean SBP lower than $130 \mathrm{~mm} \mathrm{Hg}$ or 
Table 3: Assessment of study quality for studies excluded from meta-analysis

\begin{tabular}{|c|c|c|c|c|c|}
\hline Study ID & Randomisation & Blinding & $\begin{array}{l}\text { Outcome measure: } \\
\text { Blood pressure }\end{array}$ & Loss of follow up & Funding source \\
\hline Lutomski 1984, [22] & + & ++ & Primary, Unclear & $\begin{array}{l}\text { G: } 13.7 \% ; C: 25.5 \% \\
\text { T: } 20.4 \%\end{array}$ & - \\
\hline Barrie et al. 1987, [23] & + & ++ & Primary, Mean bilateral & Unclear & Industry grant \\
\hline $\begin{array}{l}\text { Harenberg et al. } 1988, \\
\text { [24] }\end{array}$ & $\begin{array}{l}\text { No (simple } \\
\text { intervention) }\end{array}$ & Open label & Primary, Unclear & None & - \\
\hline $\begin{array}{l}\text { Kandziora J. } 1988 \\
\text { (Study 2), [25] }\end{array}$ & + & + Observer blinded & $\begin{array}{l}\text { Primary, Mean of } 2 \\
\text { readings each standing + } \\
\text { supine }\end{array}$ & Unclear & - \\
\hline $\begin{array}{l}\text { Kiesewetter et al. } \\
\text { |99|, [26] }\end{array}$ & Unclear & ++ & Unclear & Unclear & - \\
\hline $\begin{array}{l}\text { DeASantos \& } \\
\text { Gruenwald [993, [27] }\end{array}$ & + & ++ & Primary, Unclear & $\begin{array}{l}\text { G: 16.7\%; C: 10\%; T: } \\
\text { 13.3\% }\end{array}$ & Industry grant \\
\hline $\begin{array}{l}\text { DeASantos \& Johns } \\
\text { 1995, [28] }\end{array}$ & + & Open label & $\begin{array}{l}\text { Primary, Average of } 3 \\
\text { readings }\end{array}$ & $\begin{array}{l}\text { G: } 10 \% ; \mathrm{C}: 15 \% ; \mathrm{T}: \\
12.5 \%\end{array}$ & - \\
\hline $\begin{array}{l}\text { Czerny \& } \\
\text { Samochowiek 1996, } \\
{[29]}\end{array}$ & + & ++ & $\begin{array}{l}\text { Primary, Unclear (after I5 } \\
\text { min exercise) }\end{array}$ & Unclear & - \\
\hline $\begin{array}{l}\text { Mansell et al. 1996, } \\
\text { [30] }\end{array}$ & + & Unclear & Primary, Unclear & Unclear & - \\
\hline $\begin{array}{l}\text { Steiner et al. 1996, } \\
\text { [19] crossover arm }\end{array}$ & + & ++ & Primary, Unclear, manual & $\mathrm{T}: 21.2 \%$ & - \\
\hline $\begin{array}{l}\text { McCrindle et al. 1998, } \\
\text { [3I] }\end{array}$ & + & ++ & Primary, Unclear & No drop-outs & - \\
\hline $\begin{array}{l}\text { Durak et al. 2004, } \\
\text { [32] }\end{array}$ & $\begin{array}{l}\text { No (hypertensive/ } \\
\text { nomotensive) }\end{array}$ & Open label & Unclear & Unclear & - \\
\hline $\begin{array}{l}\text { Turner et al. 2004, } \\
\text { [33] }\end{array}$ & + & ++ & $\begin{array}{l}\text { Secondary, Mean of } 2 \\
\text { readings after } 10 \text { min rest }\end{array}$ & $\begin{array}{l}\text { G: } 6.1 \% ; \mathrm{C}: 5.9 \% ; \mathrm{T}: \\
6.0 \%\end{array}$ & Industry grant \\
\hline $\begin{array}{l}\text { Dhawan \& Jain 2004, } \\
\text { [34] }\end{array}$ & $\begin{array}{l}\text { Unclear } \\
\text { (hypertensives/ } \\
\text { normotensives) }\end{array}$ & ++ & $\begin{array}{l}\text { Primary, As per JNC VI } \\
\text { recommendations } 2 \times \text { after } \\
10 \text { min rest DBP } \\
\text { determined as Korotkoff } \\
\text { phase } V\end{array}$ & No drop-outs & $\begin{array}{l}\text { Council of Medical } \\
\text { Research grant }\end{array}$ \\
\hline $\begin{array}{l}\text { Jabbari et al. 2005, } \\
\text { [35] }\end{array}$ & + & Open & Primary, Unclear & $\begin{array}{l}\text { G: } 12 \% ; C: 12 \% ; T: \\
12 \%\end{array}$ & - \\
\hline
\end{tabular}

+: adequate; ++: double blinding; -: not provided; JNC: Joint National Committee

mean DBP lower than $85 \mathrm{~mm} \mathrm{Hg}$ at start of intervention (Figure 5b and 5d).

\section{Discussion}

Our meta-analysis suggests that garlic supplementation exerts a hypotensive effect compared to placebo, in particular in individuals with high blood pressure (SBP $\geq 140$ $\mathrm{mm} \mathrm{Hg}, \mathrm{DBP} \geq 90 \mathrm{~mm} \mathrm{Hg}$ ). Meta-analysis of all studies showed a mean decrease of $4.6 \pm 2.8 \mathrm{~mm} \mathrm{Hg}$ for SBP in the garlic group compared to placebo $(\mathrm{p}=0.001)$, while the mean decrease in the hypertensive subgroup was $8.4 \pm$ $2.8 \mathrm{~mm} \mathrm{Hg}$ for SBP and $7.3 \pm 1.5 \mathrm{~mm} \mathrm{Hg}$ for DBP $(\mathrm{p}<$ $0.00001)$. Low heterogeneity in the subgroup analyses in addition to regression analysis confirmed that starting blood pressure was a significant predictor for treatment effect of garlic on blood pressure.

Interestingly, garlic-only intervention arms of reviewed studies which were not suitable for meta-analysis also showed a trend for greater reduction in BP with higher starting BP. These observed trends are in line with the findings from our subgroup meta-analyses, supporting the evidence for a hypotensive effect of garlic in individuals with high or high normal blood pressure.

Whilst data from two studies [26,27], included in a previous meta-analysis [41], were not available, our meta-analysis incorporates data from six additional recent studies [15,17-21], allowing subgroup analysis and increasing generalisability. Quality of studies included in the metaanalysis was generally high, however, 20\% loss to follow up in two trials and non-reporting of drop out rates in three trials might have biased the results in those studies.

Heterogeneity observed in the meta-analyses including all studies could only partly be explained by starting BP, while dosage and duration of treatment were not associated with BP outcome. The absence of an association between dosage and blood pressure change may suggest that the hypotensive effect of garlic is comparable for dos- 
A) SBP all studies

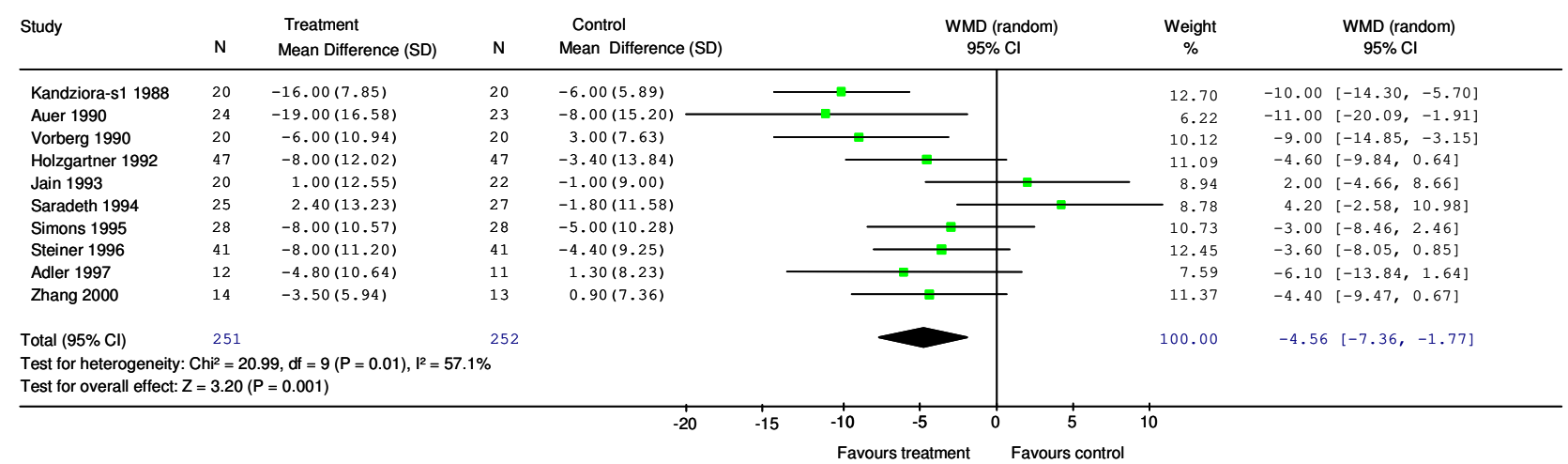

B) DBP all studies

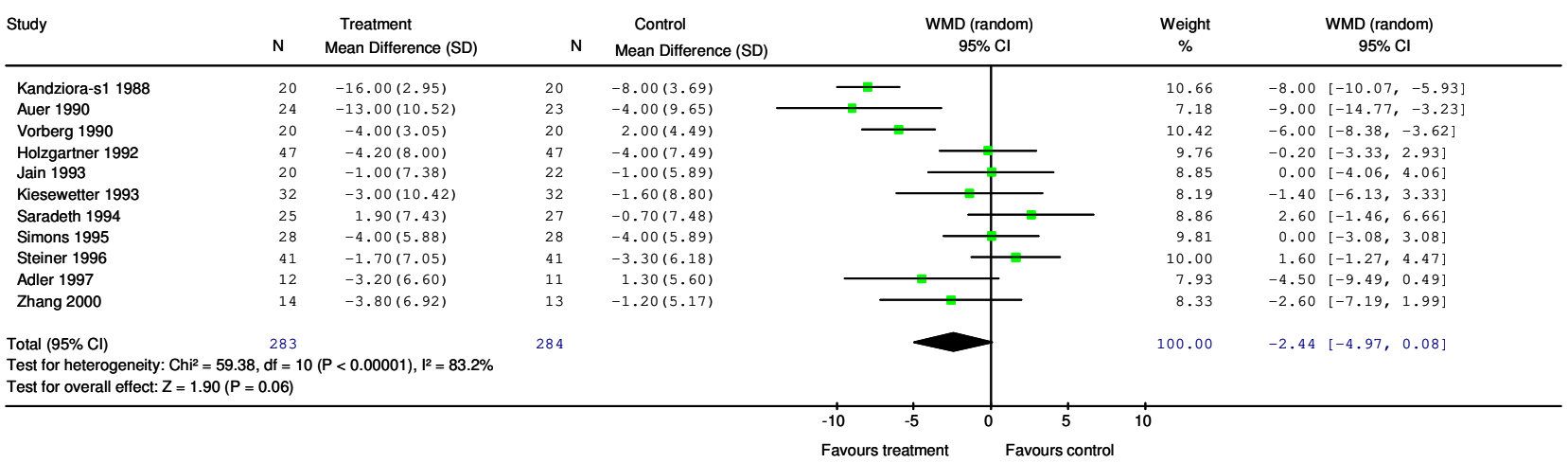

\section{Figure 2}

Meta-analysis graphs on the effect of garlic on systolic blood pressure (A) or diastolic blood pressure (B). Abbreviations: $\mathrm{N}$, number of participants; SD, standard deviation; WMD, weighted mean difference; $C l$, confidence interval; SBP, systolic blood pressure; DBP, diastolic blood pressure; sI, study I [ref II].

ages between 600 and $900 \mathrm{mg}$ per day of Kwai powder. On the other hand, detection of an association between duration of garlic intake and blood pressure change may have been limited because the majority of studies ( 7 out of 11) took final BP measurements at 12 weeks.

Our findings of the effect of garlic preparations on SBP/ DBP are comparable to the hypotensive effects of commonly-prescribed blood pressure drugs, e.g. beta-blockers of $5 \mathrm{~mm} \mathrm{Hg}$ for SBP, angiotension converting enzyme inhibitors (ACEI) of $8 \mathrm{~mm} \mathrm{Hg}$ for SBP [54], and angiotensin II type 1 receptor antagonists of $10.3 \mathrm{~mm} \mathrm{Hg}$ for DBP [55]. Our findings may have implications at a population level, where a reduction of 4 to $5 \mathrm{~mm} \mathrm{Hg}$ in SBP and 2 to $3 \mathrm{~mm} \mathrm{Hg}$ in DBP has been estimated to reduce the risk of cardiovascular morbidity and mortality by $8-20 \%$ [56]. While our study focuses on the short-term effects of garlic on blood pressure, larger scale long-term trials are needed to test the effectiveness of garlic on cardiovascular outcomes.

Most studies included in this review used garlic powder dosages of 600-900 mg per day, providing potentially 3.6-5.4 mg of allicin, the active compound in garlic [36]. In comparison, fresh garlic cloves $(\sim 2 \mathrm{~g})$ each yield 5-9 mg allicin [2]. However, different garlic preparations have variable effectiveness on blood pressure, e.g. minimal allicin compounds are found in aged garlic extract or heat treated garlic, which may limit its hypotensive properties $[4,5]$. Therefore it is advisable to use standardised garlic preparations in future trials $[57,58]$.

Supplementation with garlic preparations compared to raw garlic provides the advantage of reducing or avoiding 
A) SBP hypertensive subgroup

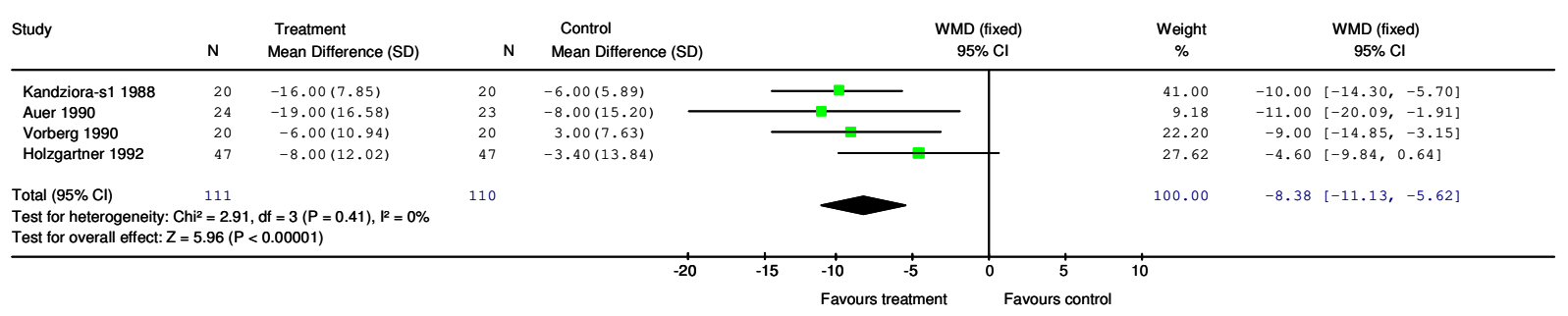

B) SBP normotensive subgroup

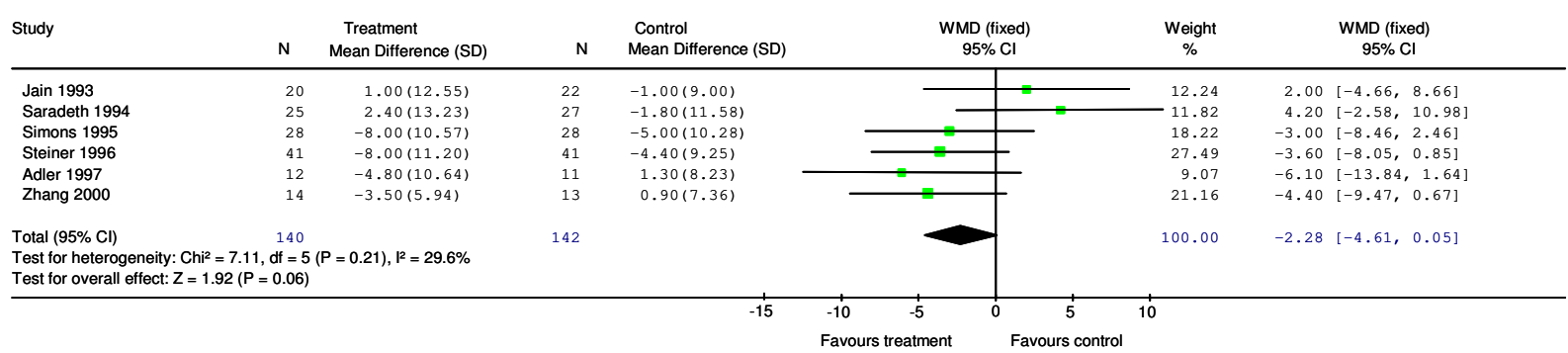

C) DBP hypertensive subgroup

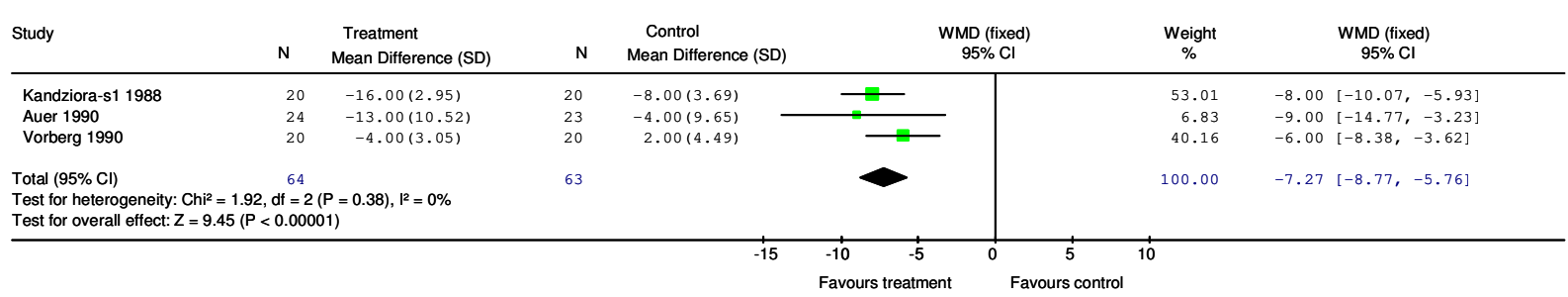

D) DBP nomotensive subgroup

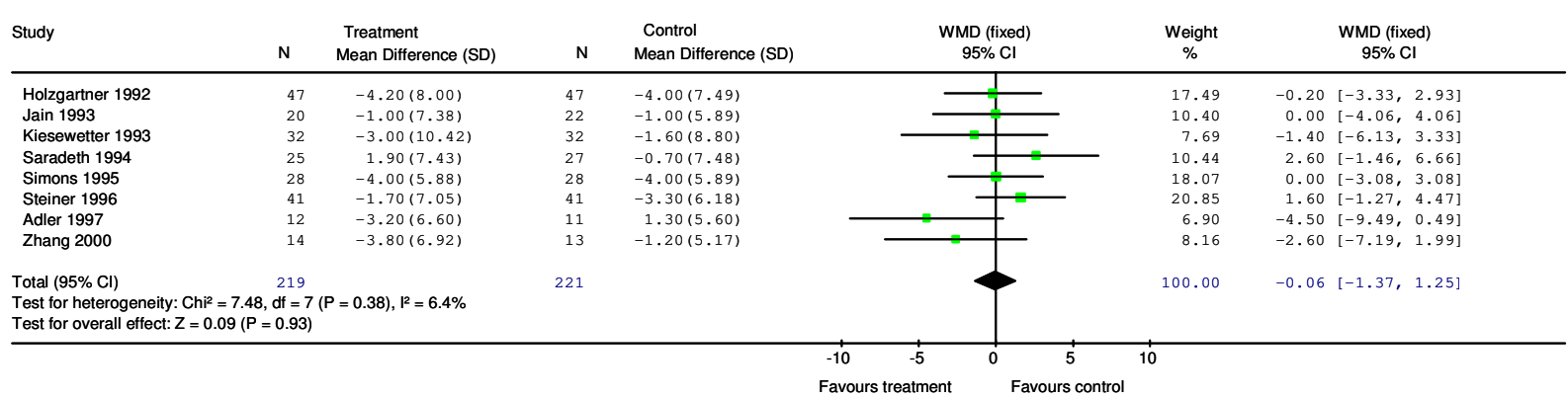

\section{Figure 3}

Subgroup meta-analysis on the effect of garlic on systolic blood pressure of hypertensive subjects $(\geq 140 \mathrm{~mm}$ $\mathrm{Hg}$ at start of intervention) (A) or 'normotensive' subjects (<140 mm Hg at start of intervention) (B); on diastolic blood pressure of hypertensive subjects $(\geq 90 \mathrm{~mm} \mathrm{Hg})(C)$ or normotensive subjects $(<90 \mathrm{~mm} \mathrm{Hg})(D)$. For abbreviations see Fig 2. 
A)

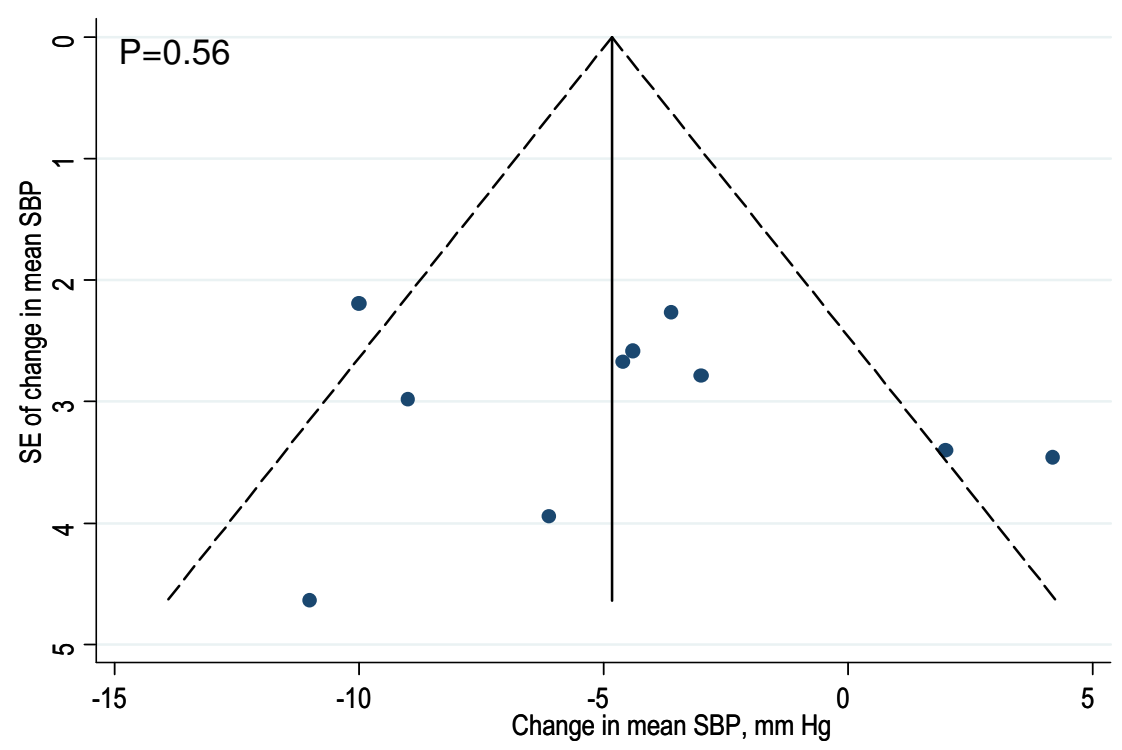

B)

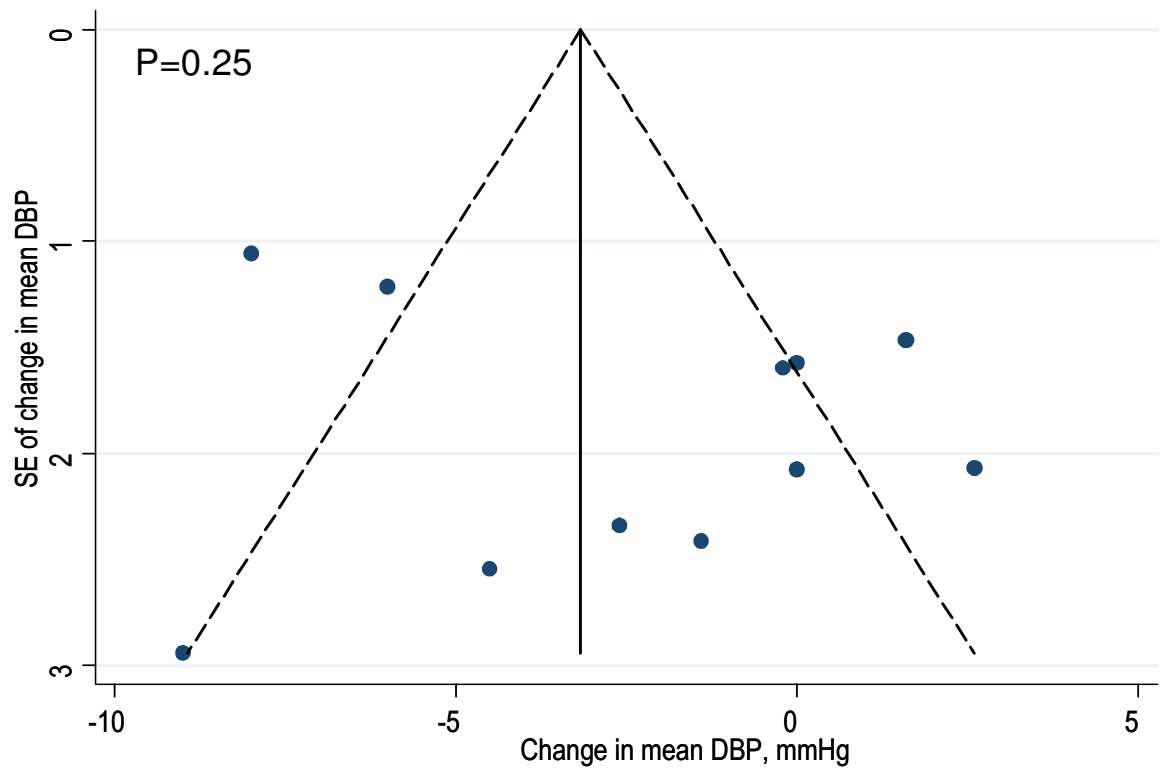

Figure 4

Funnel plots of studies included in meta-analysis on the effect of garlic on systolic blood pressure (A) and diastolic blood pressure (B). The vertical line of Begg's funnel plot represents the pooled mean effect size, the dotted lines the $95 \%$ confidence interval, $\mathrm{P}$-values are derived from Egger's test. Abbreviations: SB, systolic blood pressure; DBP, diastolic blood pressure; SE, standard error; $\mathrm{mm} \mathrm{Hg}$, millimetre mercury. 


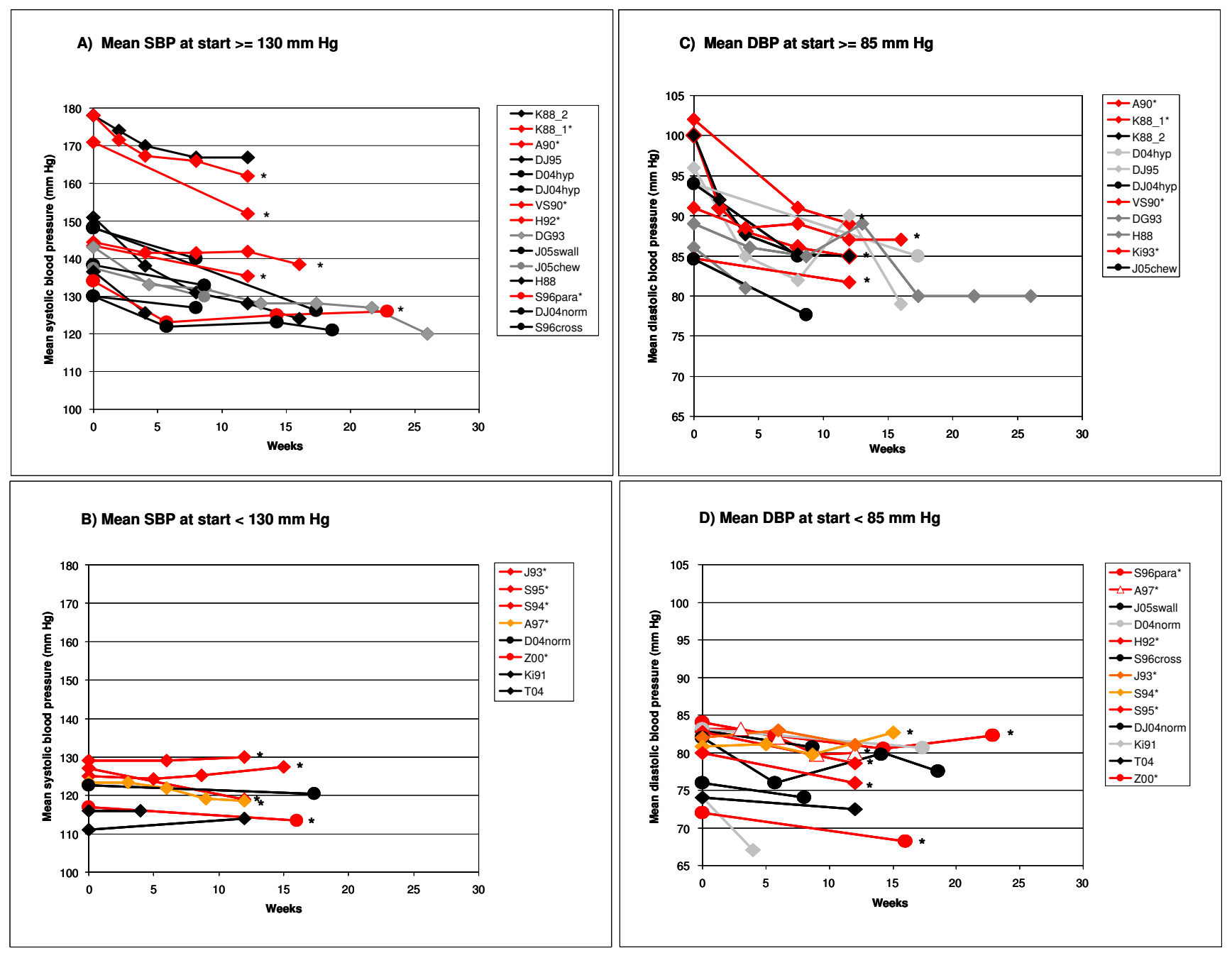

\section{Figure 5}

Mean BP against time for garlic-only intervention arm(s) of studies using subjects with $\mathbf{S B P} \geq \mathbf{I 0} \mathrm{mm} \mathrm{Hg}$ at start of intervention (A), SBP < I30 mm Hg (B), DBP $\geq 85 \mathrm{~mm} \mathrm{Hg} \mathrm{(C),} \mathrm{DBP} \mathrm{<} 85 \mathrm{~mm} \mathrm{Hg}$ (D). The plot incorporates garlic-only intervention arms of studies included in the systematic review: study arms in meta-analysis are in red/orange and marked with *, others are in black/grey. Diamonds illustrate trials using garlic powder and circles illustrate other garlic preparations. Studies in legend boxes are sorted by baseline blood pressure. Abbreviations: K88_2 = Kandziora 1988 (Study 2) [25], garlic vs drug; K88_I*=Kandziora 1988 (Study I) [I I], garlic+drug vs placebo+drug; A90* = Auer et al. 1990 [I 2]; DJ95 = De A Santos \& Johns 1995 [28]; D04hyp = Durak et al. 2004 [32], hypertensive study arm; DJ04hyp = Dhawan \& Jain 2004 [37], hypertensive study arm; VS90* = Vorberg \& Schneider 1990 [ I 3]; H92*= Holzgartner et al. 1992 [15]; DG93 = De A Santos \& Grünwald 1993 [27]; J05swall = Jabbari et al. 2005 [35], swallowing garlic study arm; J05chew = Jabbari et al. 2005 [35], chewing garlic study arm; H88 = Harenberg et al. 1988 [24]; S96para = Steiner et al. 1996 [19], parallel study arm; DJ04norm = Dhawan \& Jain 2004 [34], normotensive study arm; S96cross = Steiner et al. 1996 [19], crossover study arm; J93 = Jain et al. 1993 [16]; S95 = Simons et al. 1995 [ I 8]; S94 = Saradeth et al. 1994 [ I 7]; D04norm = Durak et al. 2004 [32], normotensive study arm ; Z00 = Zhang et al. 2000 [2I]; Ki9I = Kiesewetter 199I [26]; T04 = Turner et al. 2004 [33], median BP.

garlic breath and body odour, and prevents possible destruction of active compounds in the cooking process. Since garlic generally has a high tolerability [36], supplementation with garlic preparations may provide an acceptable alternative or complementary treatment option for hypertension.
Future research investigating a dose-response relationship between standardised garlic preparations and blood pressure would be warranted, as limited data are available [59]. Moreover, future trials could investigate whether garlic has a blood pressure reducing effect in pre-hypertensive subjects (SBP 120-139 mmHg, DBP 80-90 mm Hg), 
which may help to forestall progression to hypertension $[1,60]$.

\section{Conclusion}

This systematic review and meta-analysis suggests that garlic preparations are superior to placebo in reducing blood pressure in individuals with hypertension. Future large scale long-term trials are needed to investigate whether standardised garlic preparations could provide a safe alternative or complementary treatment option for hypertension in clinical practice.

\section{List of Abbreviations}

BP: blood pressure; CI: confidence interval; DBP: diastolic blood pressure; mg/d: milligram per day; $\mathrm{mm} \mathrm{Hg:} \mathrm{milli-}$ metre mercury; RCT: randomised controlled trial; SBP: systolic blood pressure; SD: standard deviation.

\section{Competing interests}

The authors declare that they have no competing interests.

\section{Authors' contributions}

KR, ORF and NPS conceptualised the study and obtained funding. Data was acquired independently by KR and PF. $\mathrm{KR}, \mathrm{PF}$ and TS undertook data analysis and interpretation. KR prepared the manuscript with contributions from all co-authors. All authors approved the final version.

\section{Additional material}

\section{Additional file 1}

Characteristics of studies excluded from the meta-analysis examining the effect of garlic on blood pressure.

Click here for file

[http://www.biomedcentral.com/content/supplementary/14712261-8-13-S1.pdf]

\section{Acknowledgements}

We gratefully acknowledge the assistance by the 'Adler A \& Holub B' study team who provided unpublished data for inclusion in our meta-analysis. This study was supported by the Royal Australian College of General Practitioners (RACGP) 2006 Vicki Kotsirilos Integrative Medicine Grant, and the Australian Government Primary Health Care Research Evaluation Development (PHCRED) Program.

\section{References}

I. Chobanian AV, Bakris GL, Black HR, Cushman WC, Green LA, Izzo JL Jr, Jones DW, Materson BJ, Oparil S, Wright JT Jr, et al.: The Seventh Report of the Joint National Committee on Prevention, Detection, Evaluation, and Treatment of High Blood Pressure: the JNC 7 report. Jama 2003, 289(1 9):2560-2572.

2. Lawson L: Garlic: a review of its medicinal effects and indicated active compounds. In Phytomedicines of Europe: Chemistry and Biological Activity Edited by: Lawson L, Bauer R. Washington, D. C: American Chemical Society; 1998: I77-209.

3. Benavides GA, Squadrito GL, Mills RW, Patel HD, Isbell TS, Patel RP, Darley-Usmar VM, Doeller JE, Kraus DW: Hydrogen sulfide medi- ates the vasoactivity of garlic. Proc Natl Acad Sci USA 2007. I 04(46): I 7977- I 7982.

4. Banerjee SK, Mukherjee PK, Maulik SK: Garlic as an antioxidant: the good, the bad and the ugly. Phytother Res 2003, I 7(2):97- 06.

5. Higdon J, Lawson L: Garlic and Organosulfur Compounds. Micronutrient Information Center. Linus Pauling Institute, Oregon State University. 2005 [http://lpi.oregonstate.edu/info center/phytochemicals/garlic/\#table I]. accessed 24 March 08

6. Al-Qattan KK, Khan I, Alnaqeeb MA, Ali M: Mechanism of garlic (Allium sativum) induced reduction of hypertension in $2 \mathrm{~K}$ IC rats: a possible mediation of $\mathrm{Na} / \mathrm{H}$ exchanger isoform-I. Prostaglandins Leukot Essent Fatty Acids 2003, 69(4):217-222.

7. Al-Qattan KK, Thomson M, Al-Mutawa'a S, Al-Hajeri D, Drobiova $\mathrm{H}$, Ali $M$ : Nitric oxide mediates the blood-pressure lowering effect of garlic in the rat two-kidney, one-clip model of hypertension. J Nutr 2006, I36(3 Suppl):774S-776S.

8. Kaye AD, De Witt BJ, Anwar M, Smith DE, Feng CJ, Kadowitz PJ, Nossaman BD: Analysis of responses of garlic derivatives in the pulmonary vascular bed of the rat. J Appl Physiol 2000, 89(I):353-358.

9. Mohamadi A, Jarrell ST, Shi SJ, Andrawis NS, Myers A, Clouatre D, Preuss HG: Effects of wild versus cultivated garlic on blood pressure and other parameters in hypertensive rats. Heart Dis 2000, 2(I):3-9.

10. Sharifi AM, Darabi R, Akbarloo N: Investigation of antihypertensive mechanism of garlic in 2 KIC hypertensive rat. J Ethnopharmacol 2003, 86(2-3):219-224.

I I. Kandziora J: Blutdruck- und lipidsenkende Wirkung eines Knoblauch-Präparates in Kombination mit einem Diuretikum (Study I). Aerztliche Forschung 1988, 35(3):3-8.

12. Auer W, Eiber A, Hertkorn E, Hoehfeld E, Koehrle U, Lorenz A, Mader F, Merx W, Otto G, Schmid-Otto B, et al.: Hypertension and hyperlipidaemia: garlic helps in mild cases. Br J Clin Pract Suppl 1990, 69:3-6.

13. Vorberg G, Schneider B: Therapy with garlic: results of a placebo-controlled, double-blind study. Br J Clin Pract Suppl 1990, 69:7-II.

14. Holzgartner $\mathrm{H}$, Schmidt $U$, Kuhn U: Comparison of the efficacy and tolerance of a garlic preparation vs. bezafibrate. Arzneimittelforschung 1992, 42:|473-|477.

15. Kiesewetter H, Jung $F$, Jung EM, Blume J, Mrowietz C, Birk A, Koscielny J, Wenzel E: Effects of garlic coated tablets in peripheral arterial occlusive disease. Clin Investig 1993, 7 I (5):383-386.

16. Jain AK, Vargas R, Gotzkowsky S, McMahon FG: Can garlic reduce levels of serum lipids? A controlled clinical study. Am J Med 1993, 94(6):632-635.

17. Saradeth T, Seidl S, Resch K, Ernst E: Does garlic alter the lipid pattern in normal volunteers? Phytomedicine 1994, I: |83- I85.

18. Simons LA, Balasubramaniam S, von Konigsmark M, Parfitt A, Simons J, Peters W: On the effect of garlic on plasma lipids and lipoproteins in mild hypercholesterolaemia. Atherosclerosis 1995, I I 3(2):219-225.

19. Steiner $M$, Khan AH, Holbert D, Lin RI: A double-blind crossover study in moderately hypercholesterolemic men that compared the effect of aged garlic extract and placebo administration on blood lipids. Am J Clin Nutr 1996, 64(6):866-870.

20. Adler A, Holub B: Effect of garlic and fish-oil supplementation on serum lipid and lipoprotein concentrations in hypercholesterolemic men. Am J Clin Nutr 1997, 65(445-450):

21. Zhang XH, Lowe D, Giles P, Fell S, Board AR, Baughan JA, Connock $M]$, Maslin DJ: A randomized trial of the effects of garlic oil upon coronary heart disease risk factors in trained male runners. Blood Coagul Fibrinolysis 200 I, I 2:67-74.

22. Lutomski J: Klinische Untersuchungen zur therapeutischen Wirksamkeit von Ilha Rogoff Knoblauchpillen mit Rutin. Z Phytother 1 984, 5:938-942.

23. Barrie S, Wright J, JE P: Effects of garlic oil on platelet aggregation, serum lipids and blood pressure in humans. J Orthomolecular Med 1987, 2:15-2I.

24. Harenberg J, Giese C, Zimmermann R: Effect of dried garlic on blood coagulation, fibrinolysis, platelet aggregation and serum cholesterol levels in patients with hyperlipoproteinemia. Atherosclerosis 1988, 74(3):247-249.

25. Kandziora J: Antihypertensive Wirksamkeit und Verträglichkeit eines Knoblauch-Präparates (Study 2). Aerztliche Forschung I988, 35(I): I-8. 
26. Kiesewetter $\mathrm{H}$, Jung $\mathrm{F}$, Pindur $\mathrm{G}$, Jung EM, Mrowietz C, Wenzel E: Effect of garlic on thrombocyte aggregation, microcirculation, and other risk factors. Int J Clin Pharmacol Ther Toxicol I99| 29(4): $15 \mid-155$.

27. DeASantos O, Gruenwald J: Effect of garlic powder tablets on blood lipids and blood pressure: a six-month placebo-controlled, double-blind study. $\mathrm{Br}$ J Clin Res 1993, 4:37-44.

28. DeASantos O, Johns R: Effects of garlic powder and garlic oil preparations on blood lipids, blood pressure and well-being. BrJ Clin Res 1995, 6:91-100.

29. Czerny B, Samochowiec J: Klinische Untersuchungen mit einem Knoblauch-Lezithin-Präparat. J Arztezeitschr Naturheilverf 1996, 37:126-129.

30. Mansell $P$, Reckless $P$, Lloyd L: The effect of dried garlic powder tablets on serum lipids in non-insulin dependent diabetic patients. Eur J Clin Res 1996, 8:25-26.

31. McCrindle BW, Helden E, Conner WT: Garlic extract therapy in children with hypercholesterolemia. Arch Pediatr Adolesc Med 1998, I52(II):1089-1094.

32. Durak I, Kavutcu M, Aytac B, Avci A, Devrim E, Ozbek H, Ozturk HS: Effects of garlic extract consumption on blood lipid and oxidant/antioxidant parameters in humans with high blood cholesterol. J Nutr Biochem 2004, I 5(6):373-377.

33. Turner B, Molgaard C, Marckmann P: Effect of garlic (Allium sativum) powder tablets on serum lipids, blood pressure and arterial stiffness in normo-lipidaemic volunteers: a randomised, double-blind, placebo-controlled trial. $\mathrm{Br} J$ Nutr 2004, 92(4):70I-706.

34. Dhawan $V$, Jain S: Effect of garlic supplementation on oxidized low density lipoproteins and lipid peroxidation in patients of essential hypertension. Mol Cell Biochem 2004, 266(I2):109-II5.

35. Jabbari A, Argani H, Ghorbanihaghjo A, Mahdavi R: Comparison between swallowing and chewing of garlic on levels of serum lipids, cyclosporine, creatinine and lipid peroxidation in Renal Transplant Recipients. Lipids in Health and Disease 2005, 4(I): II.

36. Ackermann RT, Mulrow CD, Ramirez G, Gardner CD, Morbidoni L, Lawrence VA: Garlic shows promise for improving some cardiovascular risk factors. Arch Intern Med 200I, I6 I (6):8I3-824.

37. Banerjee SK, Maulik SK: Effect of garlic on cardiovascular disorders: a review. Nutr J 2002, I:4.

38. Edwards QT, Colquist S, Maradiegue A: What's cooking with garlic: is this complementary and alternative medicine for hypertension? J Am Acad Nurse Pract 2005, I 7(9):38I-385.

39. Pittler $M H$, Ernst $E$ : Clinical effectiveness of garlic (Allium sativum). Mol Nutr Food Res 2007, 5 I (I I ): I382-I 385.

40. Rahman K, Lowe GM: Garlic and Cardiovascular Disease: A Critical Review. J Nutr 2006, I36(3):736S-740.

41. Silagy CA, Neil HA: A meta-analysis of the effect of garlic on blood pressure. J Hypertens 1994, I 2(4):463-468.

42. Ernst E: Complementary/alternative medicine for hypertension: a mini-review. Wien Med Wochenschr 2005, I 55(I718):386-391.

43. Yeh GY, Davis RB, Phillips RS: Use of complementary therapies in patients with cardiovascular disease. Am J Cardiol 2006, 98(5):673-680.

44. Cochrane Handbook for Systematic Reviews of Interventions. The Cochrane Collaboration [http://www.cochrane.org/ resources/handbook/]. accessed 24 March 08

45. Review Manager (RevMan) [Computer program]. Version 4.2 for Windows. Copenhagen: The Nordic Cochrane Centre, The Cochrane Collaboration, 2003 [http://www.ccims.net/RevMan]. accessed 24 March 08

46. Taubert D, Berkels R, Roesen R, Klaus W: Chocolate and Blood Pressure in Elderly Individuals with Isolated Systolic Hypertension. JAMA 2003, 290(8): 1029-1030.

47. Fleiss JL: The statistical basis of meta-analysis. Stat Methods Med Res 1993, 2(2): $121-145$

48. Higgins JP, Thompson SG: Quantifying heterogeneity in a metaanalysis. Stat Med 2002, 2 I (II): $1539-1558$.

49. Begg CB, Mazumdar M: Operating characteristics of a rank correlation test for publication bias. Biometrics 1994 50(4): $1088-1101$.
50. Egger M, Davey Smith G, Schneider M, Minder C: Bias in metaanalysis detected by a simple, graphical test. Bmj 1997, 3 I 5(7 | 09):629-634.

5I. StataCorp. 2005 Stata Statistical Software: Release 9. College Station, TX: StataCorp LP.

52. Kwai, garlic supplement [http://www.kwaigarlic.com/]. accessed 24 March 08

53. Dhawan V, Jain S: Garlic supplementation prevents oxidative DNA damage in essential hypertension. Mol Cell Biochem 2005, 275(I-2):85-94.

54. Morgan TO, Anderson Al, Maclnnis RJ: ACE inhibitors, betablockers, calcium blockers, and diuretics for the control of systolic hypertension. Am J Hypertens 200I, I4(3):24I-247.

55. Baguet JP, Legallicier B, Auquier P, Robitail S: Updated meta-analytical approach to the efficacy of antihypertensive drugs in reducing blood pressure. Clin Drug Investig 2007, 27(I I):735-753.

56. Mclnnes GT: Lowering blood pressure for cardiovascular risk reduction. J Hypertens Suppl 2005, 23(I):S3-8.

57. Lawson LD, Gardner CD: Composition, stability, and bioavailability of garlic products used in a clinical trial. J Agric Food Chem 2005, 53(16):6254-626I.

58. Lawson LD, Wang Z]: Low allicin release from garlic supplements: a major problem due to the sensitivities of alliinase activity. J Agric Food Chem 200I, 49(5):2592-2599.

59. Andrianova IV, Fomchenkov IV, Orekhov AN: [Hypotensive effect of long-acting garlic tablets allicor (a double-blind placebocontrolled trial)]. Ter Arkh 2002, 74(3):76-78.

60. Julius S, Nesbitt SD, Egan BM, Weber MA, Michelson EL, Kaciroti N, Black HR, Grimm RH Jr, Messerli FH, Oparil S, et al:: Feasibility of treating prehypertension with an angiotensin-receptor blocker. N Engl J Med 2006, 354(16): |685-1697.

\section{Pre-publication history}

The pre-publication history for this paper can be accessed here:

http://www.biomedcentral.com/1471-2261/8/13/prepub
Publish with Bio Med Central and every scientist can read your work free of charge

"BioMed Central will be the most significant development for disseminating the results of biomedical research in our lifetime. "

Sir Paul Nurse, Cancer Research UK

Your research papers will be:

- available free of charge to the entire biomedical community

- peer reviewed and published immediately upon acceptance

- cited in PubMed and archived on PubMed Central

- yours - you keep the copyright
BiolMedcentral 